УДК 130.2

\title{
Features of Cultural Reality in Cultural World View
}

\author{
Oksana G. Basalaeva* \\ Kemerovo State University of Culture and Arts \\ 17 Voroshilova, Kemerovo, 650029, Russia
}

Received 05.08.2015, received in revised form 26.09.2015, accepted 14.01.2016

\begin{abstract}
In the article the content and nature of the phenomenon of cultural world view as specialized scientific. Application of the model of the scientific world view academics V. S. Stepin allows more specifically set forth and understand the specifics of the cultural world view as specially scientific to reveal its contents and significance for philosophy and culture, and the basic functionality as a «mediator» between science and society. The cultural world view, as an aspect of social cognition, as the scientific and philosophical concept, in its content reflects the cultural reality as artificial type I (artificial and natural), in which cultural systems acquire their specific spatial and temporal forms - linear intrusion, wave, spiral, comet. The cultural reality in the cultural world view, comprises the following basic objects - artifacts that, taken together, properly organized in the cultural system. Artifacts and cultural systems are not static "objects". They arise in the process of cultural genesis, develop their inherent socio-cultural dynamics. In the socio-cultural dynamics of the allocated number of patterns that reflect the fact of their generation, evolution and function. Identified features of cultural reality to allow the content of the cultural world view holistically reproduce cultural reality as an organic and self-developing form of social reality.
\end{abstract}

Keywords: scientific world view, the cultural world view, cultural reality, social reality, artifacts, cultural systems, artificial, natural, cultural space and time.

DOI: 10.17516/1997-1370-2016-9-2-342-349.

Research area: culture studies.

\section{Introduction}

The concept of «world view» is one of the fundamental philosophy and science. But if in the XIX century view world was treated as a philosophical and ideological construct, for the XX century, especially its second half is characterized by a scientific vision view world, and at the end of XX beginning of XXI century this is scientific and philosophical belief system of the general properties and laws not only nature, but also the social environment.

The cultural view of the world is the product of philosophical and cultural research of many scientists and thinkers, which form the knowledge of culture in all its diversity - cultural reality.

\section{Theoretical framework}

Presentation of research on the cultural view world mixed. Application of the model of

C) Siberian Federal University. All rights reserved

* Corresponding author E-mail address: oksana_basalaeva@mail.ru 
the scientific view world, academicianV. Stepin (Stepin, 2003) in Cultural Studies, (1) specifies the content specialized scientific view world culture, (2) identify the specific cultural reality.

\section{Statement of the problem}

One of the means which forms world outlook of society and people's activity is a scientific view world, serving as a «mediator», a channel of communication between science, the scientific community and public opinion, civil society and the state.

Culture - one of the most important social phenomena of the modern Russian society, which is the basis for the further development of the country. Its representation in the cultural world view, the adequacy of such a representation, the communicative field this world view, requires its own understanding in order to improve the efficiency of the public consciousness and social activities to address global challenges facing Russian society.

This shows the need for increased understanding of the cultural world view in philosophy, which is not possible without revealing the specifics and the structure of the world view.

\section{Methods}

The method of conceptualism, allowed to organize empirical material on a particular area of social reality as a cultural revealed the essential features of this type of reality. Comparative Approach allowed to reflect on the content of cultural reality in the form of scientific and philosophical concept - world view.

\section{Discussion}

According to V. Stepin one of the components of the scientific world view is a flow system characteristics relevant research subject of science, serving the function description.
As for the subject of the study Cultural Studies, it is impossible to disagree with the N. P. Koptseva and N. A. Bachova. «The situation of systemic crisis provoked numerous theoretical discussions, the change of the fundamental ideologems, strength test «universal» concept of culture. It is no accident in the Russian Humanitarian Science with a persistence worthy of a better cause, for many years treading the debate on the definition of the "concept «culture»»" (Koptseva \& Bachova, 2011).

Elementary objects of cultural continuum difficult to isolation and identification due to the diversity of existing studies of various aspects of culture: ethnology, semiotics, symbolism, cultural history, etc. Apparently, the only point where they all more or less agree this is a recognition that culture is an evolving set of outbiological historically evolved modes, means and mechanisms of society - the work of M. S. Kagan, E. S. Markarian, etc. The results of this activity and the activity itself form a cultural reality, the elementary objects which are the artifacts - the results of human activity, artificially created by man objects and processes. M. Coul, based on a three-level hierarchy of M. Wartovski (Wartofski, 1973, p. 204) defines an artifact as «an aspect of the material world, transformed in the course of the history of its inclusion in a purposeful human activity. By the nature of the changes made in the process of their creation and use, artifacts are simultaneously ideal (conceptual) and material» (Coul, 1997, p. 142).

This interpretation presupposes an artifact of its artificial nature. In this regard, the artifact, acting as an artificial object, the need to include the natural environment (artificial to natural).

Artificial artifact causes the «artificiality» of the material life of man, of course, with the caveat that the artifact - is artificial to natural, i.e., the material production of life as a process of production of material goods with simple tools, 
simple machines and mechanisms, complex machines, in including vending machines, the «man - machine» robot, the production of the person who is currently in its simplest stage - in vitro conception, cloning and predicted quite so far into the future - the direct production of the human components of the natural environment artificial proteins, genes etc. This creates a human material culture.

Perceived artificiality born man of thought logic, mathematics, philosophy, and much of the content of the conceivable natural, engineering, humanities and social sciences make to talk about some of this artificial thought content. In some respects such an approach is debatable. But at the same time, there is a widely used term that in such studies has long been familiar. This term - intelligence, understood as the ability of thinking, rational knowledge, in contrast to those, for example, mental abilities, as feeling, will, intuition, imagination, etc. Intelligence is often used in conjunction with the terms «knowledge», «understanding», «sanity» and in this sense it is quite diverse semantic field. Although such «fuzziness» in the sense of intelligence, however, it attempts implemented by quantitative interpretation «factor intelligence» (IQ). A clear characteristic of this situation is, for example, the work of J. Loler. He notes that «there are two opposing understanding of intelligence: one sees it as an innate, unfailing ability, and the other involves the development of intelligence and learning. It is this second understanding of science and adhere to advocate for education, while the first, implying helplessness of man and fate, apparently, is closer to some form of religious belief. And yet, the idea of IQ is generally understood as a confirmation of the idea that intelligence - is something with which we are born, and that remains the same throughout our lives» (Loler, 1982, p. 34.). However, speaking of education, management, etc., should be recorded existence in society of intellectual culture, which should be understood as a specific kind of activity in the culture. Intellectual culture fixes to some extent artificial nature of human thought. The man in the intellectual activity by analogy with material production creates simple tools of intellectual work - presentation, then the simple machine - a concept, and then complex human intelligent systems - ideas, theories, etc.

Approval of intellectual culture, like every other individual shall initially through its aspects, for example, through the idea of artificial intelligence.

Intellectual culture is now closely linked to the information culture. Under the information culture of the person meant not only the creation, searching for information, the accumulation of knowledge, but also its understanding, comprehension (Basalaeva, 2012, p. 38)

Another consequence of the artificial nature of the elementary object of Cultural Studies - it changes and their results that a person produces in itself and, above all, in the spiritual world. This is what is called the spiritual духовной culture.

The problem of the «spirit», «spirituality»one of the central problems of philosophy. At various stages of its development, and it was getting solved in different ways. In the framework of dialectical and historical materialism, spirituality identified with social consciousness. In principle not opposed to such a decision, which is consistent with its historical time, however, we should pay attention to the fact that it is extremely difficult, as emphasized by the famous Russian philosopher of the early XX century S. Frank, «to unravel a tangle of living a spiritual life and to follow plexus forming its separate strands - the moral and philosophical motifs and ideas, you can advance only rely on approximate accuracy» (Frank, 1990. p. 81.). Since the beginning of the XX century philosophers of activity in this 
direction did not stop. We note that in the current situation «assessment of spirituality as a synthesis of all human abilities keeps the value of the ideal and goal, but real spirituality is presented in a differentiated way. ... Can distinguish at least three types of spirituality, each of which is cultivated certain professional or social group, "aestheticism" as the preferred artistic intelligentsia, and(in theirspecificmanifestations), the dominant part of the spiritual development of young people, «teoretizm» as a high scientific intellectuals and scope management, «etizm» as the focus of the professional groups related to pedagogy, journalism, fiction, and some of the less sociologically determined, but the current position in the society, such as the ratio of adults to young people. Select type of spirituality ... can ... explain some of the reasons for the lack of the social role of philosophers ...; reveal some differences in the positions of the various groups of intellectuals on philosophical issues, ask the question of where the problems of the world in the spiritual development of philosophy and the basis of their analysis of categorical» ( Fedotova, 1992, p. 78).

In each of these types of spirituality artifacts acquire the appropriate specificity - it's either «aesthetics» or «teoretizm» or «etizm».

Thus, the assertion of the artifact in an elementary object of cultural reality, focusing on its inherent characteristics in the course of its real operation allows typology, i.e., to correlate and organize seemingly disparate subject areas relevant to the culture of a group of similar artifacts on the basis of the ratio of artificial and natural: material culture (artificial in natural), intellectual culture (artificial in artificial) information culture (artificial in artificial); spiritual culture (artificial in natural). Of course, artificial in relation to natural or artificial in artificial not to be taken literally. We are talking about the dominance of certain objects and processes created by man over natural objects and processes. The man - a part of nature and can't be outside of nature.

In this case, the artifact as a set of artifacts to be seen as a kind of information or informationsemiotic system. There is plenty of visual presentation of information and semiotic concept of culture. «Once Taylor - says Lotman - defined culture as a set of tools, technical equipment, social institutions, beliefs, customs, and language. At present you can give to a more generalized definition: sum of all non-hereditary, how it is organizing and storage. However ... - Lotman writes further - culture - not a warehouse of information. It is extremely difficult to arrange a mechanism that stores information for this continually producing the most cost-effective and compact ways to receive, encrypt and decrypt messages, translates them from one system to the other characters» (Lotman, 2000, p. 395). By Iu. Lotman, the text of art fulfills three main functions: the first - is the development of new information, the second - the transfer of information, and the third - information storage (or memory function).

Thus, the cultural reality can be interpreted as an information reality, and both of their combined both aspects of social reality.

The cultural reality has inherent distinctive properties of the interaction between the artifacts and the specific characteristics of the cultural space and time.

The collection of artifacts, their synthesis are cultural system. In interaction culture systems are usually distinguished are usually three types of patterns - cultural genesis, socio-cultural dynamics and functional laws.

A variety of ideas about cultural genesis reflect the opinions or dominant (primacy) of the culture of the social environment, or dominants (primacy) of the culture of society, or represent a synthesis of anthropology, social 
theory, Cultural Studies - anthro-socio-cultural genesis (look for example: Kagan, 1996, pp. 319-402.). Without going into the details and specifics of these concepts in a simplified form as a kind of essence of cultural genesis of social dynamics of culture is in the process of existence and variability of culture, in the continuous generation of new cultural phenomena, along with inheritance and the transformation of the former (look for example: Flier, 1995, p. 18.). «In all the variety of functions of culture emphasizes A. Flier - can be identified such «profile» areas as social-integrative, cognitive, communicative, organizational - regulatory normative, recreational and estimated» (Cultural Studies, 1998).

Specifying the item on the spatio-temporal characteristics of cultural reality represented in the cultural world view is logical to speak of space-time forms of the objects of this reality the artifacts and cultural systems.

«Premises» culture in nature, of course, leads to the recognition of the results of the natural sciences as fundamental. But the specifics of artifacts and built of them cultural systems the global civilization, local cultures and, in the end, the artifact with a capital letter - of the people, allowing to talk about the features of space and time as applied to the culture. In this sense we can talk about the global, universal space and time in culture as a common human culture - the macro-level concepts of space and time, which are actually physical space and time. But it may be reasonable to talk about the micro-level concepts of space and time to which the person belongs as an individual, as a person, and generated operating in a particular cultural system.

Generally accepted concepts of space are such common features as properties of the objects to be extended, to take the place of others, bordering with other objects. The concepts of time are based on the concept of duration, its rhythm and pace.

This understanding is translated from natural science to philosophy, history, and Cultural Studies. When considering the spatial and temporal characteristics of cultural systems and their interaction can be fixed four main points of view on the movement (evolution) of cultural systems with regard to their spatial and temporal characteristics of the macro-level. Linearlyintrusive, characterized evolution in a linear space and time, but reaches increasingly or complexity of the organization or the die in the process, or to assimilate other systems. Undulating (wave packet) which exist quite a long time and they can be seen the wave processes in various fields of the system. Spiral-cultural systems, the evolution of (motion), which is carried out through an internal reorganization for the «movement disintegration - integration - is not a circle but a spiral. Another integration will take place at a different level, a different concept ...» (Cantor, 1997, p. 48). Finally, comet culture systems that have their spatio-temporal shape.

At the micro level of cultural processes, that is, at the level of individual artifacts and cultural artifacts in the main - the Man, the space and time appear slightly different. Indicative in this case is the concept of V. Kruglikov's. The author expresses it as follows. «But if the culture - it is always a border area, border, if a cultural act of man - it is always a moment, the moment of overcoming the limits and being on the border, on the existence of a «razor's blade» and if a person has cultural-thinking and cultural-sentient substance, then naturally it should be a form of existence of matter. These forms of matter known - space and time. At the same time, the philosophical-anthropological concept of cultural forms of life of the individual has long embodied in the language of philosophy as individuality and personality» 
(Kruglikov, 1987, p. 171-172). And then the author continues, «the analysis of the concept of «human culture» as a possible analogue of space and time, the person to use symbols of individuality and personality ... Then the personality and the decree refers to the location of the individual in person. In turn, the person can be represented as a semantic sweep the «I» of a person's time, such as the subjective time in which to make movements, movements and personality changes» (Kruglikov, 1987, p. 172173). These movements can be described as a «lifestyle», «lifeway», «personality change», etc. In this case, the objective space and time becomes the subject, become internal time of culture and its individual artifact - the Man.

Understanding the symptoms of space and time in culture is also reflected in the concept of M. Bakhtin's chronotope, introduced them to the art culture. «A significant relationship of temporal and spatial relations, artistically developed in the literature, we call the chronotope (which means in a literal translation - «timespace»). This term, as used in the mathematical and natural sciences was justified and implemented on the basis of the theory of relativity (A. Einshein). For us, it is important that special sense which it has in the theory of relativity, it is important expression ... it continuity of space and time (time as the fourth dimension of space).

In literary and artistic chronotope is a merging of space and time to take concrete and meaningful whole. Time here is condensed, compacted, it becomes art and visible, the space is intensifying, is drawn into the movement of time, plot and history. Signs of the times are disclosed in space, and space is interpreted and measured by time. This intersection of the series and is characterized by the fusion of art will chronotope» (Bakhtin, 1975, p. 121). Pointing to the importance of administration M. Bakhtin hronotop's L. Mikeshina notes the following.
«Bakhtin left a kind of model for the analysis of temporal and spatial relations and ways of their" introduction "in the artistic and literary texts, which can serve as a model, in particular, for the study of cognitive texts» (Mikeshina, 1999).

Thus, the time-space in the interpretation of M. Bakhtin as a condition for the concept of subjective time V. Kruglikova

In the process of being cultural systems acquire their specific spatio-temporal forms linear intrusion, wave (wave packet), spiral, comet. Such space-time system move designed (originate, develop, evolve and die) in the globalhistorical, cultural space-time continuum, and in each cultural form in its inner structure of space and time are specified, well-defined way.

\section{Conclusion}

Summing up the cultural representation of reality in the cultural world view, we note that fixed her elementary objects - artifacts that, taken together, properly organized in the cultural system. Cultural systems as overbiological system with built-in social-cultural programs, in contrast to the genetic programs of living organisms represent a kind of artificial reality I kind.

The complex internal structure of the artifact is still waiting for attention from researchers, but the extent to which it is disclosed and understood lets say that hidden in the content, if the trend reversal to the outside world, let them serve as a basis of typology cultural systems, which are a set of specific areas of culture - the material culture, intellectual culture, information culture, spiritual culture.

Artifacts and cultural systems are not static «objects». They arise in the process of cultural genesis, evolve (develop) their inherent dynamics - the socio-cultural dynamics, and function in socio-cultural-anthropologist continuum. Within the socio-cultural dynamics identifies a number of laws, which reflects both 
the fact of their generation, their evolution and function

Thus, represented in the cultural world view cultural reality has its special and specific nature as opposed to, for example, the physical reality represented in the physical world view or the reality of the information reality in the information world view, etc.

\section{References}

Bakhtin, M. M. (1975). Forms of time and chronotope in the novel. Essays on historical poetics. Questions of literature and aesthetics (pp. 234-407). Moscow.

Basalaeva, O. G. (2012). Social and philosophical aspects the interrelation of information and cultural world view: diss... PhD of philosophical sciences. Kemerovo.

Coul, M. (1997). Cultural-historical psychology. Moscow.

Cultural Studies. The XX century (1998). Encyclopedia. St. Petersburg.

Fedotova, V. (1992). Practical and spiritual development of reality. Moscow.

Flier, A. Ia. (1995). Cultural genesis. Moscow.

Frank, S. (1990). Works. Moscow.

Kagan, M. S. (1996). Philosophy of Culture. St. Petersburg.

Kantor, K. (1997). Deintegration-integration helix of world history, , Questions of philosophy, (3), pp. 31-47.

Koptseva, N. P. \& Bachova, N. A. Culture system Krasnoyarsk region: the main actors and cultural values, Expert Club «Development Committee», 26.08.2011, available at: expertclub.info/content/ kopceva-np-bahova-na-sistema-kultury-krasnoyarskogo-kraya-osnovnye-subekty-i-kulturnye.

Kruglikov, V. A. (1987). Space and Time «man of culture», Culture, man, and world view (pp. 167-197). Moscow.

Loler, J. (1982). Factor intelligence heredity and racism. Moscow.

Lotman, Iu. (2000). Semiosphera: Culture and explosion. Inside the E-minded moat. Article. Research. Notes (1968-1992). St. Petersburg.

Mikeshina, L. A. The value of Bakhtin's ideas for modern epistemology, Philosophy of science, 1999, Vol. 5, available at: iph.ras.ru/page50567562.htm

Stepin, V. S. (2000). Theoretical knowledge: the structure, the historical evolution. Moscow.

Wartofski, M. (1973). Models. Dortrecht: D. Reidel. 


\title{
Особенности культурной реальности \\ в культурной картине мира
}

\author{
О.Г. Басалаева \\ Кемеровский государственный университет \\ культуры и искусств \\ Россия, 650029, Кемерово, ул. Ворошилова, 17
}

\begin{abstract}
В статье раскрыты содержание и сущность феномена культурной картины мира как частнонаучной. Применение модели научной картины мира академика В. С. Степина позволяет более конкретно изложить и понять специфику культурной картины мира как частнонаучной, раскрыть ее содержание и значение как для философии и культурологии, так и основное функииональное назначение как «посредника» между наукой и обществом. Культурная картина мира как аспект сочиального познания в качестве научно-философского концепта в своем содержании отражает культурную реальность как искусственное I рода (искусственное в естественном), в которой культурные системы обретают свои специфические пространственно-временные формы - линейно-интрузионную, волновую, спиральную, кометную. Культурная реальность в культурной картине мира включает следуюшие элементарные объекты - артефакты, которые в своей совокупности соответствующим образом организованы в культурные системы. Артефакты и культурные системы не являются статичными «предметами». Они возникают в проиессе культурогенеза, эволюиионируют (развиваются) с присущей им соииокультурной динамикой. В социокультурной динамике выделяется ряд закономерностей, отражающих факт их порождения, эволюиию и функиионирование. Выявленные черты культурной реальности позволяют в содержании культурной картины мира целостно воспроизвести культурную реальность как органическую и саморазвивающуюся форму соииальной реальности.
\end{abstract}

Ключевые слова: научная картина мира, культурная картина мира, культурная реальность, социальная реальность, артефакты, культурные системы, искусственное, естественное, культурное пространство и время.

Научная специальность: 24.00.00 - культурология. 